\title{
INVESTIGATING THE ISSUE OF MIXED MARRIAGES IN MALACHI, EZRA-NEHEMIAH AND THE PENTATEUCH
}

Fanie Snyman

University of the Free State

\begin{abstract}
This contribution investigates the issue of mixed marriages in the book of Malachi, Ezra-Nehemiah and the Pentateuch. It is found that mixed marriages in Malachi are denounced on religious grounds while in Ezra-Nehemiah nationalistic motivations such as language and culture also come into play. Malachi most probably draws on the legal traditions in the Pentateuch, notably Deuteronomy 7:1-8, to motivate his stance on mixed marriages. What is interesting is that the Pentateuch also tells various stories about prominent figures in the history of Israel who married foreign women without being judged for doing so. In fact, what they did is told approvingly. Does this mean that there are two traditions at play here: one a more legal approach denouncing mixed marriages and secondly a more pragmatic approach approving mixed marriages? Is the Old Testament/Hebrew Bible consistent in its view on this matter?
\end{abstract}

Key Words: Mixed Marriage; Malachi; Ezra-Nehemia; Deuteronomy 7

\section{Introduction and Problem Statement}

The problem addressed in this contribution is to examine the issue of mixed marriages briefly as it is reflected in Mal. 2:10-12 taken as a sample text from the corpus propheticum, the books of Ezra-Nehemiah taken as a sample text from the Writings and the Pentateuch. What does the phrase "to marry the daughter of a foreign god" in Malachi 2:11 mean? How does this view cohere with similar points of view in the books of EzraNehemiah? Thirdly, the issue of mixed marriages will also be viewed against the background of the Pentateuch. Is the Old Testament/Hebrew Bible consistent in its view on this issue? The investigation starts off by a careful reading of the Malachi text. Then cursory attention will be paid to the issue of intermarriage in Ezra-Nehemiah, focusing briefly on how the approach of Ezra-Nehemiah differs from Malachi and finally the issue of intermarriage will be considered as it presents itself in the Pentateuch.

\section{Intermarriage in Malachi}

Reading the Text of Malachi 2:10-13

${ }^{10}$ Do we not all have one Father? Did not one God call us into being? Why is a man then treacherous against/unfaithful to his brother to profane the covenant of our fathers?

${ }^{11}$ Judah was unfaithful/acted treacherously and a detestable thing was done in Israel and Jerusalem. Judah profaned/violated the sanctuary of Yahweh, the one he loved, and married the daughter of a foreign god. 
${ }^{12}$ May Yahweh cut off the man who does this from the tents of Jacob - each and everybody/[literally: the one who is awake and the one who responds] - whilst bringing an offering to Yahweh the Almighty.

\section{General Remarks}

While the notion of marriage assumes a relationship between a man and a woman, women are not addressed in the Malachi passage. To be a foreigner and a woman who marries a Judean man is not considered in the first part of the unit (Mal. 2:11-12). It is rather the (religious) consequences of such a marriage that is the focus of attention. The plight of women as the victims of divorce is likewise not considered in the second part of the unit (Mal. 2:13-16). Once again the consequences of divorce, rather than how it may effect divorced women, are highlighted.

It has been said time and again by scholars that Malachi 2:10-16 can be considered the most difficult part of this brief prophetic book. Hill ${ }^{1}$ maintains: "Scholars are unanimous in their assessment of 2:10-16 as a notoriously difficult text to interpret". Willi-Plein ${ }^{2}$ in her commentary on this passage remarked: “...das der Abschnitt Mal. 2,10-16 sowohl in Bezug auf den Textbestand, als auch in Bezug auf der Frage der Einheitlichkeit und nicht zuletzt auch im Blick auf die Bedeutung der Einzelsätze und ihrer Kohärenz untereinander schwierig ist". The text presents the reader with a host of problems on almost every level of interpretation: text critical problems, grammatical problems, phrases that are difficult if not impossible to make sense of, all of which result in difficulties in determining the message of this unit. ${ }^{3}$ Meinhold ${ }^{4}$ in his major commentary on Malachi remarks in this regard: "Mit dem III. Diskussionswort verbinden sich Fragen, die im Lauf der Forschung, auch aufgrund der teilweise sehr schwierigen, vereinzelt sogar für völlig unverständlich gehaltenen Textgestalt, recht unterschiedliche Antworten gefunden haben”.

\section{Literary Considerations}

Scholars are in agreement that Mal. 2:10-16 constitutes a separate unit. The unit commences with a rhetorical question to which every Judean would agree: We all have one Father, the one who created us. This is the typical way in which a new unit in the book commences (Mal. 1:2;1:6;2:17; 3:7b, 3:13). A new theme is introduced, namely that of marriage and divorce, that is different from the previous unit where the sacrificial system as performed by both the people and the priesthood was addressed. In Mal. 2:17-3:7a yet another theme different from Mal. 2:10-16 is introduced. The vocabulary (בגד חלל עשה) used in Mal. 2:10-16 is also a clear indication that this unit serves as an independent unit.

Numerous attempts were made especially by German scholars to reconstruct the growth of the unit from a so-called Grundlage ${ }^{5}$ but recently the unity or the "Einheitlichkeit des Textes" was also defended. ${ }^{6}$

The unit in question displays a chiastic structure. The pericope commences with a general introduction. It is then followed by separated but linked parts. The first part starts with an offence committed (verse 11) "Judah was unfaithful and a detestable thing was done in Israel and Jerusalem", followed by the consequences of the offence (verse 12): "May YHWH cut off the man who does this from the tents of Jacob...". The second part of the unit clearly indicated by 'secondly' deals first with the religious consequences (verse 13) - YHWH does not pay attention to the people's offering or accepts them with pleasure from their hands - and then followed by the offence committed (verses 14-16) "you have 
broken faith with her, though she is your partner, the wife of your marriage covenant". In this sense the unit clearly displays a chiastic structure:

(a) The offence committed, Judah acted treacherously bgd (בגד) (v11);

(b) The religious consequences, Yahweh will cut off a man doing this (v12);

(b1) The religious consequences, covering the altar with tears will be to no avail (v13);

(a1) The offence committed, men have been unfaithful bgd (בגד) to their wives (vv14-16).

The chiastic structure indicates that although the unit forms a distinct pericope, it can also be divided into two sub-units after the introduction in Mal. 2:10 (Mal. 2:11-12 and 2:13-16 respectively). In Mal. 2:13 the text reads 'and secondly" (וזאת שנית) indicating a different but related topic that will be treated. The verb 'casa' (כסה) occurs in verse 13 and then again in verse 16 thereby creating an inclusion strengthening the argument that verses 13-16 should be taken as a sub-unit within Mal. 2:10-16.

It is interesting to note that in the first part of verse 11 the feminine form of בגד is used to describe the actions of Judah while in the second part of the verse the masculine form (חלל) of the verb is used. It seems best to explain the use of the feminine verb form as a description of Judah as a country and when Judah is described as a nation or people the masculine form is used. ${ }^{7}$ Is it possible that the feminine and masculine forms are used as a subtle indication of the two parties involved in a marriage?

The overall theme of the unit is that of marriage but two different problems are addressed. In the first part Judean men who marry foreign women are addressed and in the second part of the unit the issue of divorce is addressed. The sequence of the two violations addressed is also important. Commentaries assume that married Judean men are addressed in both parts of the unit. In the first part it seems rather that unmarried Judean men are addressed. Judean men who married foreign women worshipping a foreign god are reprimanded not to do so. It just seems logical that in the first part unmarried men will be addressed. In the second part married Judean men are addressed not to divorce the wives to whom they are married.

\section{Historical Considerations}

The book originated during the post-exilic period after the temple has been rebuilt in 515 $\mathrm{BC} / \mathrm{E}$. Placing the book after Haggai and Zechariah indicates that the book has to be situated after the temple has been rebuilt in post-exilic times. Malachi 1:10;3:1 and 3:10 refer to the temple and it seems reasonable to assume that the post-exilic (second) temple is meant. The term peha (פחה) in Malachi 1:8 refers to a Persian government official and serves as a strong indicator of a date sometime during the Persian time. The exact dating of Old Testament texts is always a disputed matter. In recent literature on the book the tendency is to date the book later. ${ }^{8}$ The date preferred for the sake of this contribution is 460-450 BC/E, making it roughly contemporaneous with ministry of Ezra and Nehemiah. No mention is made of the return from the exile or a recently completed temple so that a date close to $515 \mathrm{BCE}$ seems improbable.

Data that can be gained from the book itself suggest that it was a time of spiritual and moral decay in the community of Judean territory. Sacrifices were brought in a disinterested way and with neglect to the prescriptions stipulated in the Torah (Mal. 1:6-2:9; $2: 10-16 ; 2: 17-3: 7 a ; 3: 7 b-12 ; 3: 13-23)$. The society suffered from moral decay in terms of marriages (Mal. 2:10-16) and in the way in which people treated one another (3:5). It was a 
time of religious skepticism where people questioned the love of God (Mal. 1:2-5) and his ability to guide his people to a good life (Mal. 3:13-23).

\section{Marriage in Malachi 2:10, 11-12}

The offence addressed is mentioned in verse 11: "Judah was unfaithful and a detestable thing was done in Israel and Jerusalem. Judah profaned the sanctuary of Yahweh, the one he loved, and married the daughter of a foreign god". Judean men apparently entered into a marriage with "the daughter of a foreign god". What this phrase - only to be found here in the Hebrew Bible - means, is not entirely clear at once. Some scholars thought of the phrase as a metaphor for worshipping another goddess. To worship another goddess or gods resulted in profaning the sanctuary of YHWH. The metaphor of a marriage would then convey the meaning that Judean men worshipped a foreign goddess. The majority of commentators reject this line of interpretation. ${ }^{9}$ Glazier-McDonald ${ }^{10}$ for instance, argues that by the same line of argumentation the phrase "children of YHWH" can be understood as god which it clearly not the case, while Stuart" says that the term "daughter of a foreign god" would be an unnatural term for 'goddess'.

The interpretation that most commentators hold on this issue is that the phrase refers to a woman who remains loyal to a god other that YHWH even after she married a Judean man to become her husband. Meinhold ${ }^{12}$ makes it clear when he states "Deutlich aber ist, dass sie einem anderen Zugehörigkeits- und Verehrungsverhältnis als die Judäerinnen und die Judäer, die alle JHWH zum Vater haben, eingefügt ist". Weyde ${ }^{13}$ came to a similar conclusion: "the reference of the phrase (married the daughter of a foreign god) is to marriage between men of Judah, who worship YHWH, and women who worship a foreign god". Willi-Plein's ${ }^{14}$ conclusion is the same: "In Mal. 2,11 geht es also um eine Liebesbeziehung mit einer Frau, die selbst 'einer fremdländischen Religion angehört'."

Following this line of interpretation an interesting irony emerges: All Judean men share the same one God as Father and Creator according to verse 10. By depicting the woman as a "daughter of a foreign god" she also has a god as her father seeing that she is portrayed as a daughter of a foreign god. The metaphor of 'daughter' implies the foreign woman worships a god who is her father just as the Judean people have God as their father. Both the husband and the wife then have G(g)od as father. O'Brien ${ }^{15}$ observes: “....intermarriage takes a man outside the community into the domain of another father; 'daughter of a foreign god". Kessler ${ }^{16}$ makes the observation that the woman referred to may not even be a foreign woman from another culture - it may even be a Judean woman no longer worshipping YHWH but another god. It is not marrying a foreign woman that is at stake here. It is a foreign woman worshipping a foreign god that is criticized. ${ }^{17}$

If this line of interpretation is valid then the view that the phrase "Do we not all have one Father" in verse 10 refers to all people and not only the Judean people cannot be supported. The distinction between Judean men and the women they wish to marry goes back to the different 'fathers' they have and consequently the G(o)ds they worship.

\section{Family Relationships in the Book of Malachi}

It is interesting to note that family relationships play a prominent part in the book. Three metaphors using family relationships are used in the book: the metaphor of brothers, the father:son metaphor and the husband:wife metaphor. 
The first unit (Mal. 1:2-5) recalls the troubled Jacob-Esau brotherhood. Although Jacob and Esau were brothers, even twins, the animosity between these two brothers is a dominant theme in the Jacob traditions as portrayed in the book of Genesis. The story of these two brothers (twins) is a story of deceit and envy. The theme of the brothers JacobEsau is also found elsewhere in the Book of the Twelve (Am. 1:11; Ob. 10, 12) where the animosity between the brothers is transposed to the relationship between Israel and the Edomites as different but related peoples.

While the first pericope utilizes the brotherly relationship between Jacob and Esau, Jacob is at the same time also one of the patriarchs of the Judean people. The people addressed in the book are seen as "the children of Jacob" (Mal. 3:6-7a) meaning that the Judean people descend from Jacob (Israel), the one after whom they are called as Israelites.

In Mal. 2:10 God as father emerges as a metaphor for depicting the relationship between the people and God. This metaphor used in Mal. 1:6 is picked up again in Mal. 3:17 although the word 'father' is substituted by 'man'. In Malachi 1:6 the honour a son has for his father is contrasted with the apparent disrespect Judah has for YHWH as their father. Echoes of the call to honour one's father are found in the wisdom literature (Prov. 10:1; 15:20) as well as in the Pentateuch, especially in the Decalogue (Exod. 20:12; Dt. 5:16). The Hebrew term kbd (כבד) denotes respect more than anything else. This generallyaccepted truth is then applied to the relationship between YHWH and the Judean people. As a father may expect his son to honour him, so God as the people's father may expect honour from his people as his sons.

The same relationship between father and son is used again later in the book (Mal. 3:17) when the father:son relationship is a metaphor for the relationship between YHWH and his people. The way in which God deals with Israel is compared to the way a father deals with his son. The relationship between father and son should be understood from the patriarchal culture at the time of the book so that one should not think here in terms of a sentimental relationship between father and son. Because of the fact that the God-fearers serve God they will experience his empathy on the day of judgment. It is important to note that as was the case in 1:6 the father:son relationship becomes the metaphor for viewing the relationship between God and his people. God as the father of his people expects honour (1:6) and the people from their side may expect that God will act as a father is expected to act, by sparing his son in the day of disaster $(3: 17)$. The conclusion of the book $(3: 22-24)$ sees a return to the father:son relationship when it is foreseen that the disrupted relations between fathers and sons will eventually be restored.

The God as father metaphor encountered in Mal. 1:6 is picked once again in the pericope under discussion: "Do we not all have one Father? Did not one God create us into being?" In this case it is the close relationship between God as father and God as Creator that is striking. It is interesting to note that the father metaphor for God is found only in Malachi in the book of the Twelve.

In the pericope under consideration (Mal. 2:10-16) it is the husband:wife metaphor that is used. Two aspects related to marriage are addressed. Unmarried Judean men are reprimanded for marrying women who worship a foreign god and married men are reprimanded for divorcing the wives to whom they are married. In the next unit (Mal. 2:17$3: 7$ a) the plight of widows is addressed where it is said that they should not be oppressed (Mal. 3:5).

Judean men marrying foreign women still worshipping their god(s) opens up an interesting irony. Using the metaphor of marriage to describe the relationship between 
YHWY and the Judean people is a well-known one especially from the book of Hosea. Here in Malachi the (female) 'wife' of YHWH acts as a (male) husband but at the same time the husband is treacherous in the relationship with YHWH by marrying a "daughter of a foreign god," thereby allowing for idolatry. This subtle suggestion of the relationship between YHWH and his people as a marriage is prompted by depicting Judah in verse 11 as feminine (בגדה יהדה but in verse 12 masculine verb forms are used to describe the actions of Judah as the male ancestor of the people.

This short overview shows that family relationships play an important part in the book as a whole, covering a range of different family relationships.

What is interesting is the silence of the woman in question. She is not addressed, neither would she carry the punishment announced in verse 12. Another aspect that is not addressed is why Judean men would consider foreign women to be their wives. Stuart ${ }^{18}$ suggests that money and sex were the major motives for inter-marriage. He argues that the Judeans returned to an impoverished land with a destroyed capital and an economy that was under the control of foreigners. Stuart ${ }^{19}$ further bases his argument upon the assumption that the men addressed in the first part of the unit are the ones who divorced their Judean wives because foreign cultures will allow it more easily. However, the fact that the warning against marriages rather presumes that it is addressing unmarried men who are still on the lookout for possible wives. Furthermore, there is no indication in the text on what may motivate Judean men to marry foreign women or to divorce the wives to whom they are married. The issue of intermarriage may simply be part of the general demise of the people's adherence to the Torah of YHWH, an issue addressed elsewhere in the book as well (Mal. 3:5, 3:13). The arguments he provided therefore do not convince and can be considered as speculation.

\section{Intermarriage in the Books of Ezra-Nehemiah}

In the books of Ezra-Nehemiah the same issue is addressed. ${ }^{20}$ In Ezra 9-10 the issue of intermarriage receives extensive attention. According to Ezra 9:1-2 the leaders approached Ezra and informed him that "the people of Israel, including the priests and the Levites, have not kept themselves separate from the neighbouring nations... They have taken some of their daughters as wives for themselves and their sons, and have mingled the holy race with the peoples around them. And the leaders and the officials have led the way in this unfaithfulness". Ezra was appalled on hearing this (Ezra 9:3) and offered a prayer of confession and eventually led the people to repentance, expecting them to "separate yourselves from the peoples around you and from your foreign wives" (Ezra 10:11). The people agreed and a process was started to investigate this matter. Quite significantly, the book comes to and end with a list of names of people who married foreign women (Ezra 10:18-43).

The same issue is addressed in the book of Nehemiah. According to Nehemiah 13:23 Nehemiah "saw men of Judah who had married women from Ashdod, Ammon and Moab. Half of their children spoke the language of Ashdod or the language of one of the other people, and did not know how to speak the language of Judah". The fact Nehemiah mentions the women from Ashdod adds a political dimension as well because according to Nehemiah 4:7-8 the people of Ashdod were angry together with Sanballat, Tobiah, the Arabs and the Ammonites and they all conspired to fight against Jerusalem. ${ }^{21}$

It is at once apparent that the issue of intermarriage in Ezra and Nehemiah is considered in a far more serious light than in Malachi. Meinhold ${ }^{22}$ is in agreement: "Die Mischehen- 
frage ist in Esra/Nehemia überaus wichtig und gegenüber Mal. 2,11ff sehr ausgeweitet" while Noetzen ${ }^{23}$ maintains that "die Mischehenfrage hier nicht so radikal entschieden worden sei wie in Esr. 9f". While in Malachi only a single verse is devoted to this issue, the case is different in Ezra where the issue is dealt with in elaborate terms involving prayer, confession and eventually ending up in a decision that men who married foreign women should separate themselves from their foreign wives. It seems that the custom persisted during the ministry of Nehemiah. In the Malachi text separation or divorce is not treated as an option to consider. In Ezra-Nehemiah mixed marriages are prohibited more on nationalistic and cultural grounds, like the language issue, than from religious motivation. Kessler $^{24}$ remarks in this regard: "In Esr. 9-10 wird die religiöse Problematik als solche gar nicht benannt". For Ezra and Nehemiah the danger of intermarriage lies with the cultural identity of the people. ${ }^{25}$ In Ezra-Nehemiah foreign people are named (Ashdod, Ammon, Moab) while in Malachi no mention is made of the nationality of the "daughter of a foreign god". In Ezra-Nehemiah names of Judean men are listed while in Malachi the issue is addressed in more general terms.

In this sense, Malachi has a far softer approach on the issue than in the books of Ezra and Nehemiah. The question that arises is of course why there is this difference in approach. Different answers can be given to this question. Firstly, Malachi's approach will be in line with a more tolerant outlook on the foreign nations co-existing with the Judean in the post-exilic Persian time. Malachi 1:11 comes into play in this regard. This is a controversial text in the book which has provoked different interpretations. It is unlikely that the text may be interpreted as worship of YHWH by foreign people. The most plausible explanation is that the text refers to Jews in the diaspora worshipping YHWH outside of the borders of the province of Judah and the city of Jerusalem or the temple. If this is the case, it is an indication that the prophet does not have a narrow interpretation of where $\mathrm{YHWH}$ may be worshipped as he does not limit the legitimate worship of YHWH only to the temple in Jerusalem. According to Vriezen ${ }^{26}$ Malachi has a broad concept of God considering the many ways in which YHWH is pictured in the book (YHWH, El, Father, Lord). Malachi 3:5 mentions the foreigner (ג) explicitly, who may not be thrust aside or deprived of justice. YHWH demands justice (משפט) and he will act as a judge to see whether justice was practiced, including justice towards the foreigner. These texts serve as an indication that Malachi did not have a narrow-minded approach and hence his more lenient attitude towards the issue of intermarriage.

If this line of argumentation holds valid, it is probably safe to assume that Malachi had his ministry shortly before Ezra-Nehemiah. The more lenient approach Malachi followed did not have the expected results and Ezra-Nehemiah had to take a stronger approach on the issue of intermarriage, expanding the motivation on this prohibition to more than only religious grounds.

Thirdly, if it is assumed that Malachi delivered his prophesies after the time of EzraNehemiah it might be that Malachi reacted to the harsh approach propagated by EzraNehemiah by adopting a more tolerant approach, warning against the dangers of intermarriage where religious differences are the main point.

\section{Intermarriage in the Pentateuch}

Scholars are more or less in agreement that the prohibition on intermarriage can be traced back to Pentateuch traditions, notably Deuteronomy 7:1-8. ${ }^{27}$ For Meinhold ${ }^{28}$ Deuteronomy 7 should be regarded as a "massgeblichen Hintergrundtext" and according to Noetzel ${ }^{29}$ it is 
clear that the prohibition of mixed marriages goes back to Deuteronomy 7:1-8. Israelites are prohibited to intermarry with the seven nations of Canaan. It is said explicitly that Israelites may "not give your daughters to their sons or take their daughters for your sons" (Deut $7: 3$ ). The motivation for this prohibition is also clear: "for they will turn your sons away from following me to serve other gods..." (Deut 7:4). Intermarriage with a foreign woman is forbidden because this might lead to idolatry. ${ }^{30}$ It should also be noted that the term 'foreign god' occurs in Deuteronomy 32:12.

Verse 11b, "Judah profaned/violated the sanctuary of Yahweh, the one he loved" may also be seen as an allusion to Leviticus 19:8, "Whoever eats it will be held responsible because he has desecrated what is holy to the Lord; that person must be cut off from his people" (NIV). Weyde (2000:227) pointed out that the phrase קדש יהוה can only be found in Leviticus 19:8 and Malachi 2:11 in the Hebrew Bible. What is further noteworthy is that

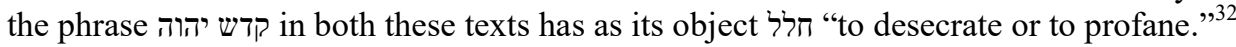

It seems possible that Malachi draws on traditions from both Leviticus (the Holiness Code in particular) and Deuteronomy in 2:11. This is also the conclusion Kessler ${ }^{33}$ came to when he states: "Es bleibt damit ganz im Rahmen dessen, was durch die Torahbestimmungen. von Ex 34,15 und Dtn 7,2-4 vorgegeben ist".

\section{Intermarriage in the Narrative Parts of the Pentateuch}

It is however interesting to note that instances of intermarriage occurred within the Pentateuch and apparently the custom is not criticized.

Abraham married Sarah and was related to her (Gen. 12:10-20). Interestingly enough, when Abraham impregnated Sarah's Egyptian maidservant, Hagar, Abraham did not object nor did the narrator of the story make any negative comment. After the death of Sarah, Abraham married Keturah (Gen. 25:1) but no mention is made of her nationality. Isaac did not marry a foreign woman. One of Abraham's slaves was sent to "my country and the country of my own relatives" (Gen. 24:4), and Rebekah, the sister of Laban (Gen. 24:29) turned out to be the bride for Isaac. Genesis 31 tells the story of Jacob's flight from his uncle and father-in-law. Laban accused Jacob of stealing his gods. It turns out that Rachel stole the gods or teraphim (Gen. 31:34) and by doing so in a strange way she became the daughter of a foreign god even though she is strictly speaking not a foreign woman. Once again the story is told approvingly.

In Genesis 38:1-5 one reads about Judah, Jacob's son, and one of the patriarchs of the Judean people. He left his brothers and stayed with Hirah, a man of Adullam. Then is it said that he met a Canaanite woman who was the daughter of Shua and was eventually married to her. This is reported in a matter-of-fact way and with no negative judgment on his choice of a Canaanite woman.

Joseph married an Egyptian woman named Azenath, daughter of an Egyptian priest (Gen. 41:45). Being a daughter of an Egyptian priest she would almost certain worship the $\operatorname{god}(\mathrm{s})$ her father worshipped and that would place her in the category of the a "daughter of a foreign god." In fact, according to van Selms ${ }^{34}$ the name of Joseph's wife means "she who belongs to the goddess Neith". Once again the marriage with a foreign (Egyptian) woman is stated and is neither approved nor disapproved. Von $\operatorname{Rad}^{35}$ remarked how Joseph's "not quite unobjectionable inclusion into the Egyptian court is related and is rather surprising in the light of Israel's faith" - even more so, the marriage of Joseph with an Egyptian woman. Brueggemann ${ }^{36}$ remarks that Joseph became completely encapsulated in Egyptian reality. This all happened through the royal proclamation (Gen. 41:41), the 
insignia of office (Gen. 41:42), public acclamation (Gen. 41:43), a royal name (Gen. 41:45) and finally legitimacy by marriage (Gen. 41:45). Ultimately, their sons, Manasseh and Ephraim, were born becoming one of the strongest clans in Israel and fully adopted by their grandfather, Jacob (Gen. 48:5).

Moses married Zipporah, a Midianite woman and daughter of a Midianite priest (Ex $2: 21$ ) and the marriage is simply reported without a verdict of whether it was in accordance or against current practices. Through the mysterious incident told in Exodus 4:24-26 Zipporah is portrayed as a strong woman saving her husband from death and performing the ritual of circumcision of her son. The fact that Jethro is called the father-in-law of Moses in Exodus 18:5 is seen as an expression of approval of the marriage. ${ }^{37}$ It is ironic that Moses, the mediator of the Torah, trespasses one of the stipulations of the very Torah he brought to the people.

In Numbers 12 the story of Moses' marriage to a Cushite woman is told. Numbers 12:1 seems to emphasize the fact that Moses indeed married a Cushite wife. What is remarkable about this incident is that when Aaron and Miriam are not happy with this marriage, YHWH steps in and sides with Moses. It is said that "the anger of the Lord burned against them" (Num 12:9) and Miriam was struck by leprosy. By implication then, Moses, in his marriage and prophetic role, is above criticism by Israel's priestly (Aaron) and prophetic (Miriam) leadership. ${ }^{38}$ Winslow's conclusion is that this passage reflects a polemic against those who attacked mixed marriages on 'ethnic' grounds ${ }^{39}$.

Is it possible that while the legal parts of the Pentateuch speak out against mixed marriages on religious grounds, a more pragmatic approach is reported in the narrative parts of the Pentateuch where well-known figures married foreign women and it is reported in an approving way? Clearly, there is a discrepancy between the laws of the Pentateuch and the narratives told in the Pentateuch. In this contribution I want to suggest four possible answers to explain this obvious discrepancy. Is it possible that the stories simply reflect the need of a man to have a woman in marriage, irrespective of the nationality or religious convictions of a foreign wife? A second possibility is that a more pragmatic approach is reported in the narrative parts of the Pentateuch to counter the strict legal parts of the Pentateuch reflecting a difference of opinion in the Second Temple period. It is also possible that it is assumed that the foreign women became worshippers of YHWH because of their marriage to prominent figures in Israelite history. A fourth possibility is that the narrative parts inform the readers that marriages to foreign women, although forbidden in the legal parts, are also tolerated. It is significant to note that all the marriages to foreign women reported in the Pentateuch were conducted on foreign soil in a land beyond the borders of Israel (Midian, Egypt).

\section{Intermarriage Elsewhere in the Old Testament/Hebrew Bible}

Elsewhere in the Old Testament/Hebrew Bible other instances of intermarriage are also reported. ${ }^{40}$ Samson engaged repeatedly in marital relationships with Philistine women (Judg 14:4).

King Solomon and the many wives he had are well-known. Solomon and his wives received a negative report from the authors of the Deuteronomistic History and was highlighted as one of the major factors contributing to his downfall. Other kings mentioned in the Deuteronomistic History also married foreign women and this contributed to their eventual downfall. 
The book of Ruth is another case in point. At the beginning of the book it is stated that two Judean men originally coming from Bethlehem, married Moabite women. No judgement is delivered upon these marriages. Throughout the book Ruth's national identity as a Moabite woman is stated. She adhered however not to her (former) Moabite gods but pledged allegiance to YHWH, the God of Israel. Therefore, as a Moabite woman who married a Judean husband Ruth was welcomed without any problems as part of the people of God. Ruth then represents a foreign woman who cannot be labelled the daughter of a foreign god. Later she married Boaz and again nothing negative was reported, to the contrary, Ruth became the great grandmother of king David. ${ }^{41}$

The book of Esther may also be mentioned here. ${ }^{42}$ To a certain extent Esther may be seen as the opposite of Ruth. Esther was a Judean woman (Est. 2:7) who engaged in a marriage with a foreign king. From a Persian perspective she was the daughter of a foreign god who used her position as queen to the benefit of her people. Knoppers investigated this problem in the book of Chronicles. ${ }^{43}$

\section{Conclusion}

The book of Malachi in Mal. 2:10-12 presents us with a unique contribution to the often thorny issue of intermarriage. Malachi warns primarily against the religious consequences of such marriages in that it may lead to idolatry which is unacceptable, unlike his contemporaries Ezra and Nehemiah who argued the issue also on nationalistic and cultural considerations. To bring his message home he draws on Pentateuch traditions. Within the Pentateuch there seems to be a twofold view on the matter of mixed marriages. On the one hand, mixed marriages are forbidden in the law codes. On the other hand, the narrative parts of the Pentateuch tell stories in an approving way of mixed marriages of prominent figures in the history of Israel. The problem stated at the beginning of this contribution was: Is the Old Testament/Hebrew Bible consistent in its view on this issue? The answer to this question is no, different answers to this question were given.

\section{Epilogue}

With this I article I wish to honour Prof. H.L. (Bossie) Bosman, an Old Testament scholar in the true sense of the word and a friend over so many years and to express my sincere gratitude to him for his vast contribution to Old Testament scholarship in South Africa and the rest of the world during his career.

\section{BIBLIOGRAPHY}

Botterweck, G.J. "Schelt- und Mahnrede gegen Mischehen und Ehescheidung," BibLeb (1960):179-185.

Brueggemann,W. Genesis. Interpretation. Atlanta: John Knox, 1982.

Dor, Y. "From the Well in Midian to the Baal of Peor: Different Attitudes to Marriage of Israelites to Midianite Women". Pages 150-169 in Mixed Marriages and Group Identity in the Second Temple Period. Edited by C. Frevel. London: T\&T Clark, 2011.

Floyd, M.H. Minor Prophets: Part 2. FOTL XXII. Michigan: Wm B Eerdmans, 2000. 
http://scriptura.journals.ac.za

Investigating the issue of mixed marriages in Malachi, Ezra-Nehemiah and the Pentateuch

Frevel, C. (ed.). Mixed Marriages and Group Identity in the Second Temple Period. London: T\&T Clark, 2011.

Fuller, R. "Text-Critical Problems in Malachi 2:10-16." JBL (1991):47-57.

Glazier-McDonald, B. Malachi - The Divine Messenger. SBL Dissertation Series 98. Atlanta, Georgia: Scholars Press, 1987.

Glazier-McDonald, B. “Malachi 2:12: ‘er we'oneh - Another Look.” JBL (1986):295-298.

Glazier-McDonald, B. "Intermarriage, Divorce and the Bat 'el nekar.” JBL (1987):603-611.

Hill, A. E. Malachi: A New Translation with Introduction and Commentary. AB 25D. New York: Doubleday, 1998.

Hugenberger, G.P. Marriage as a Covenant: A Study of Biblical Law and Ethics Governing Marriage Development from the Perspective of Malachi. OTS 52. Leiden:

Brill, 1994.

Kessler, R. "Die interkulturellen Ehen im persezeitlichen Juda." Pages 276-294 in Moderne Religionsgeschichte im Gespräch. Interreligiös - Interkulturell - Interdisziplinär:

Festschrift C Elsas. Edited by A. Herrmann-Pfandt. Berlin. EB Verlag, 2010.

Kessler, R. Maleachi. HThKAT. Freiburg: Verlag Herder, 2011.

Knoppers, G. "Married into Moab: The Exogamy practiced by Judah and his Descendents in the Judahites Lineages". Pages 170-191 in Mixed marriages and group identity in the Second Temple Period. Edited by C. Frevel. London: T\&T Clark, 2011.

Meinhold, A. Maleachi. BKAT XIV/8. Neukirchen-Vluyn: Neukirchener, 2006.

Noetzel, J. Maleachi, ein Hermeneut. BZAW 467. Berlin: de Gruyter, 2015.

O’Brien, J. M. “Judah as Wife and Husband: Deconstructing Gender in Malachi.” JBL (1996):241-250.

Ogden, G.S. "The Use of Figurative Language in Malachi 2.10-16.” BT (1988):223-230.

Rudolph, W. Haggai, Sacharja 1 - 8, Sacharja 9-14, Maleachi. KAT XIII/4. Gütersloh: Gerd Mohn, 1976.

Rudolph, W. “Zu Mal. 2, 10-16.” ZAW(1981):85-90.

Schreiner, S. "Mischehen - Ehebruch - Ehescheidung." ZAW (1979):207-228.

Shields, M.A. "Syncretism and Divorce in Malachi 2:10-16." ZAW (1999):68-86.

Snyman, S.D. "Wie en Wat Word Veroordeel - en Waarom? Nog eens Maleagi 2:10-16." IDS (2006):19-34.

Stuart, D. "Malachi," in The Minor Prophets: An Exegetical and Expository Commentary. Edited by T.E. McComiskey. Vol. 1. Grand Rapids: Baker Book House, 1998.

Van Selms, A. Genesis deel II. Pout. Nijkerk: Callenbach, 1967.

Von Rad, G. Genesis A Commentary. OTL. London: SCM, 1972.

Vriezen, Th.C. "How to understand Malachi 1:11" in Grace upon Grace: Festschrift J. Kuyper. Edited by J.I. Cook. Grand Rapids: Wm. B. Eerdmans. 1975, 128-136.

Winslow, K.S. "Mixed Marriages in Torah Narratives". Pages 132-149 in Mixed marriages and group identity in the Second Temple Period. Edited by C. Frevel.

London: T\&T Clark, 2011.

Weyde, K.W. Prophecy and Teaching. Prophetic Authority, Form Problems and the Use of Traditions in the Book of Malachi. BZAW 268. Berlin: de Gruyter, 2000.

Willi-Plein, I. Haggai, Sacharja, Maleachi. ZBK. Zürich: Theologischer Verlag, 2007. 


\section{Endnotes}

1 A.E. Hill, Malachi: A New Translation with Introduction and Commentary, AB 25D (New York Doubleday, 1998), 222.

2 I. Willi-Plein, Haggai, Sacharja, Maleachi. ZBK. (Zürich: Theologischer Verlag, 2007), 256.

3 G.J. Botterweck, "Schelt- und Mahnrede gegen Mischehen und Ehescheidung," BibLeb (1960): 179-185;

G.S. Ogden, "The Use of Figurative Language in Malachi 2.10-16," BT (1988): 223-230; R. Fuller "TextCritical Problems in Malachi 2:10-16," JBL (1991): 47-57.

4 A. Meinhold, Maleachi. BKAT XIV/8 (Neukirchen-Vluyn: Neukirchener, 2006), 184.

5 W. Rudolph, Haggai, Sacharja 1-8, Sacharja 9-14, Maleachi. KAT XIII/4 (Gütersloh: Gerd Mohn, 1976); Meinhold, Maleachi; Willi-Plein, Haggai, Sacharja, Maleachi.

$6 \quad$ R. Kessler, Maleachi. HThKAT (Freiburg: Verlag Herder, 2011), 187.

7 P.A. Verhoef, The Books of Haggai and Malachi. NICOT. (Grand Rapids: Wm B Eerdmans, 1987) 267-268, B. Glazier-McDonald, Malachi - The Divine Messenger. SBL Dissertation Series 98 (Atlanta, Georgia: Scholars Press, 1987), 89.

$8 \quad$ Kessler, Maleachi, 75-77, Meinhold, Maleachi, 22-24.

9 D. Stuart, "Malachi," in The Minor Prophets: An Exegetical and Expository Commentary, ed. T.E. McComiskey; Vol. (Grand Rapids: Baker Book House, 1998), 1333.

Glazier-McDonald, Malachi, 92.

Stuart, Malachi, 1333.

Meinhold, Maleachi, 208.

3 K.W. Weyde, Prophecy and Teaching. Prophetic Authority, Form Problems and the use of Traditions in the book of Malachi, BZAW 268. (Berlin: de Gruyter, 2000), 231.

14 Willi-Plein, Maleachi, 261.

15 J.M. O’Brien, “Judah as Wife and Husband: Deconstructing Gender in Malachi,” JBL (1996): 247.

16 Kessler, Maleachi, 198, R. Kessler, "Die interkulturellen Ehen im persezeitlichen Juda,” in Moderne Religionsgeschichte im Gespräch. Interreligiös - Interkulturell - Interdisziplinär: Festschrift C. Elsas, ed. A. Herrmann-Pfandt (Berlin. EB Verlag, 2010), 288. M.H. Floyd, Minor Prophets: Part 2. FOTL XXII. (Michigan: Wm B Eerdmans, 2000), 607.

8 Stuart, Malachi, 1333.

19 Stuart, Malachi, 1333.

20 The matter of inter-marriage in the books of Ezra and Nehemiah has been investigated thoroughly in the recent past and therefore the reader is referred to the relevant literature in this regard. Cf. Mixed Marriages and Group Identity in the Second Temple Period, ed. C. Frevel (London: T\&T Clark, 2011).

Meinhold, Maleachi, 194-195.

Meinhold, Maleachi, 190.

J. Noetzel, "Maleachi, ein Hermeneut" BZAW 467. (Berlin: de Gruyter), 161-162.

Kessler, Maleachi, 197.

Meinhold, Maleachi, 192.

26 Th. C. Vriezen, "How to understand Malachi 1:11," in Grace upon grace: Festschrift J. Kuyper, ed. J.I. Cook (Grand Rapids: Wm B Eerdmans 1975), 134.

Meinhold, Maleachi,207.

Noetzel, Maleachi, 153.

Weyde, Prophecy and Teaching, 232-233.

Weyde, Prophecy and Teaching, 227.

Meinhold, Maleachi, 206.

Kessler, Maleachi, 198; Kessler, "Die interkulturellen Ehen", 188.

A. Van Selms, Genesis deel II. Pout. (Nijkerk:Callenbach, 1967), 214.

G. Von Rad, Genesis A Commentary. OTL. (London: SCM, 1972), 378.

W. Brueggemann, Genesis. Interpretation. (Atlanta: John Knox, 1982), 334.

37 Y. Dor, "From the Well in Midian to the Baal of Peor: Different Attitudes to Marriage of Israelites to Midianite women", in Mixed Marriages and Group Identity in the Second Temple Period, ed. C. Frevel. (London: T\&T Clark 2011), 151. 
38 K.S. Winslow, "Mixed Marriages in Torah Narratives", in Mixed Marriages and Group Identity in the Second Temple Period, ed. C. Frevel (London: T\&T Clark 2011), 148.

39 Winslow,Mixed Marriages, 148.

40 Winslow, Mixed Marriages, 150.

41 Dor, From the Well, 165; Winslow, Mixed Marriages, 151.

42 Winslow, Mixed Marriages, 151.

43 G Knoppers, "Married into Moab: The exogamy practiced by Judah and his descendents in the Judahites lineages, in Mixed marriages and Group Identity in the Second Temple Period, ed. C. Frevel (London: T\&T Clark 2011), 170-191. 